\title{
Surviving by the grace of god: perception of the older adult
}

\begin{abstract}
Objective: To know the perception that the older adult has about his old age, in a nursing home of the city of Popayán.

Materials and methods: The study presented a qualitative approach of type phenomenological; the method of the observation was used, developed in 300 hours. There were realized 25 open interviews recorded in audio and written in field diaries and we worked with 8 older adults with an average age of 75 years \pm 6.34 .

Results: There were demonstrated two categories after to the thematic analysis and interpretation of the interviews: A) God my support and foundation to live. B) The economic dependence: a limitation for the personal and social development.

Conclusion: It was possible to demonstrate that the older adults increase his religious beliefs and attribute to God the fact of having a home and food. In the same way, it was concluded that the older adults believe themselves persons dependent and unable to work, because with the oldness, his health deteriorates and this it has negative implications in his social, economic and familiar sphere.
\end{abstract}

Keywords: perception, older adult, health, religion, dependency
Volume 3 Issue 2 - 2018

\author{
Nancy Janneth Molano Tobar,' Luz Marina \\ Chalapud Narváez ${ }^{2}$ \\ 'Departamento de Educación Física, Universidad del Cauca, \\ Colombia \\ ${ }^{2}$ Facultad de Educación, Corporación Universitaria Autónoma \\ del Cauca,Colombia
}

\begin{abstract}
Correspondence: Nancy Janneth Molano Tobar
Departamento de Educación Física, Recreación y Deporte Universidad del Cauca, Cauca, Colombia, Tel 57+2+8209800,
\end{abstract} Email,najamoto@unicauca.edu.co

Received: February 15, 2018 | Published: March 02, 2018

\section{Introduction}

Old age is considered as a stage of great physical, emotional, and social changes, which differs from the linking of factors such as lifestyle, region and country. ${ }^{1}$ Nowadays, at worldwide level, is evidence of the growth of the older adult population, ${ }^{2}$ made up by people above 60 years of age, ${ }^{3}$ who are affected by the changes of the aging process, ${ }^{4}$ which have an impact on their physical, social and emotional development. It is important to keep in mind that, at the level of the policies of public health seeks to ensure that this population has a good quality of life, ${ }^{5}$ therefore, promoting strategies such as physical activity, health care centers, among others. However, in spite of that, most of the time doesn't take into account the pillar of these strategies, the older adult. ${ }^{6}$

It is critical to have knowledge about the level of physical, psychological, social and family condition of the population, ${ }^{7}$ but to know the perception that has the older adult about his old age, will allow to establish strategies that generate impact, not only on their quantity of life, but also in their quality of life, ${ }^{8-10}$ also to demonstrate the worldview that the individual has about the old age, stage to which the majority of the population will come with or without illnesses, or with high sociocultural changes that they bear him to be lived in an asylum.

It is important to determine that the perception is a subjective and independent construct influenced by social, educational, cultural factors and by personal and familiar situations as the experience, ${ }^{11,12}$ due to this it turns out difficult to associate this perception with an alone identification of characteristics, because of it an approximation is realized to this population from his present and past experiences, to show what they think, they feel and live nowadays from a nursing home.
The physical or functional limitations in the older adult diminish or annul his productive activities, causing an economic and social dependence. This population is seen like useless, generating processes of discrimination and lack of opportunities, ${ }^{13}$ the public policies look for the protection of the older adult, but are strategies suitable? Or are we leading to this population to developing feelings of rejection, abandon, uselessness and begging? An important aspect to contextualize strategies of attention to this population they are his beliefs - the religiousness- a coadyudante to establish a major adhesion to processes, as the Rivera-Ledesma and Montero-Lopez mentions when the persons going through critical situations in his life, they resort to God and the prayer as adaptable resources to the changes, those changes involve the cessation of labor activities and in the worst case the abandon and rejection on the part of his relatives, this supposes the revenue to refuges or nursing homes far from his favorite activities, his social circle and his family.

The religiousness plays an important paper in the confrontation of the changes that the older adults suffer with relation to the loss of his functionality, his home, his family and as active member of the society, because there has been demonstrated that it diminishes the mortality in chronic cases, increases self-esteem, diminishes the anxiety and the depression, between other benefits. ${ }^{14,15}$

The intention of this investigation was to reveal the perception that the older adults have about the immersed life in an institution of attention to the geriatric population.

\section{Materials and Methods}

The approach of this study had qualitative methodologies with the objective of demonstrating the connotation of the spiritual and social sphere in the older adults of a nursing home. The design was 
phenomenological-hermeneutic, based on lived experience, and according to Ayala Carabajo, ${ }^{16}$ who exposes the ideas of Van Mane, there is no evidence of a method as a set of procedures, but it is about the study of the meaning of the phenomena, oriented to obtaining descriptions of lived experiences, using conversational interviews and close observation. The techniques that were used for the qualitative part were the observation, which developed in 300 hours, and the opened interview to 25 persons, recorded in audio and written in the field diaries. The information was transcribed, checked, categorized and codified. The fieldwork was realized between the first and second period of 2017.

\section{Participants}

The men who participated, belong to an asylum in the city of Popayán and they attended freely and spontaneously to the meetings works in the same city. The sample was realized by convenience and corresponded to 20 men and 8 key informants, with an average age of 75 years \pm 6.34 . It was considered the inclusion criteria as: living in the nursing home for more than two years, that the participants were not demonstrated pathologies associated with psychiatric disorders, which they were attended meetings works and chosen to sign the assent informed in which they there was guaranteed the ethical and anonymous managing of the information supplied, with the assignment of codes of analysis handled by numbers and the statement for the letter $\mathrm{R}$, followed by the session in which it was realized.

\section{Process}

From the qualitative methodology, the used approach was phenomenological hermeneutical, proposed by Martin Heidegger ${ }^{17}$ this approach consisted of defining a phenomenon or a problem of investigation, to know the God's connotation that the older adults have of a nursing home, later, an investigative process was developed to access to the knowledge of the state of the art, where there was realized a search of precedents relating to the topic of investigation and with the theoretical knowledge, were realized meetings with the older adults, first to achieve an approximation and to win his confidence with recreational activities, then, it was developed open discussions under the modality of interviews in depth, taking field diaries of every meeting, this allowed to identify common parameters, after a rereading of the material and classification of the information, in units of analysis that glimpsed the essential themes of the phenomenon, which were refined through coding techniques, thematic and interpretative analysis, ${ }^{18}$ for this process the MAXQDA program was used in its version 12 .

\section{Ethical-legal aspects}

Was taken into account the established in Helsinky's Resolution and in the Resolution 8430 of the Department of Health and Social Protection of Colombia for the investigation with persons; a chat was given to the group of support for the investigation about ethical aspects and how the approaches and meetings had to be assumed, also the project was made known to the asylum and to the older adults, previous endorsement of the ethics committee of the University Autonomous Corporation of Cauca and once explained and understood, there was completed the format of informed consent, where the protection is guaranteed to the intimacy, to the confidentiality and to the right to the anonymity of the information supplied like with the interviews, considering the study with minimal risk of injury for the participants.

\section{Results and discussion}

We worked with two categories, which were obtained of the investigative process developed after the triangulation of data: A) God my support and foundation to live. B) The economic dependence: a limitation for the personal and social development.

With every passing year, the beliefs appear in a stronger way, for this reason in the adult age God represents a support and across Him, the persons obtain housing and supply, of the same way, they think that the God's kindness keeps them healthy and alive, which is $\mathrm{He}$ who gives them health, well-being and life. This can be visualized in the statements of the older adults, expressed below:

"The asylum is the God's house, I lost my house. [...] It was Him who gave to me this inn, because I was sick and I didn't have anybody who was helped me and God said: this boy has to remain here below, and it was Him who told me: stay here" (R7A1). "For now, I am sick and can't do anything with my body, don't have help, don't have relatives, I have only the support of God and the Virgin, I don't have anyone else [...] only for the God's goodness I'm still here" (R7A2).

It is clear that, the spirituality is relevant in Colombia, because from the childhood (years 50-70) the existence of a God and his laws like foundation to act and to take decisions of life, has been immersed in the study plans and in the homes, because of it, Rubio et al. ${ }^{19}$ it exposes that " the religious fact " is present in the history of the humanity and explains how the faith helps to face the human complexity; the belief in God is strongly established in the group of older adults who did part of this study, since thanks to Him they have a house and food. On the other hand, Merino ${ }^{20}$ demonstrates how the man has changed this type of thoughts, to the point of he not being interested in the revelations and beliefs and of denying the God's existence, demonstrating a contrast between the experiences and beliefs of the past and present.

The interviews realized also put in evidence the increase in the problems of health that the older adults suffer, according to Parra Rizo $^{21}$ the ageing is associated with the increase of not transmissible diseases as the disability that brings with it social and economic consequences for the individual and social health.

In the second category, "The economic dependence: a limitation for the personal and social development" there is demonstrated how the process of disease limits the older adults at the moment of realizing different activities and being independent, this has led them to asking for help to survive. This is how it is possible to observe that the body is an instrument of action and of independence that leads them to having possibilities of working and to support themselves economically. We can read about this in the following statements: "The life is a constant fight and with the passage of time, it turns into a force impossible to win, [...] the oldness makes me think that however much I want, I cannot obtain many things for my account, in addition it is difficult that to this age I could get a job" (R4A7). "[...] the first thing is that I can't go out to the street, I am without exit and the second thing is that when they have to give me the money that belongs to me, they don't give it to me then I depend economically on them" (R3A3).

For the older adults, the oldness implies a loss of his both physical and economic independence, because his body limits them, Rizo García ${ }^{11}$ affirms that, the body is the vehicle for the human interaction, because it represents the stability and it is the support of our identity. For the older adults, the oldness represents the loss of opportunities, 
because now they are immersed in a fragile and disabled body, which prevents them from going out, from working and having economic independence, in Ferrante's et al. ${ }^{22}$ words, when the man can't realize an activity freely, is reduced to "a dependent, unskillful and sick body". From Berumen's ${ }^{23}$ point of view, this reduction of the body is understood as an alone conception of capital body, knowing that the body is a dynamic system, full of meanings and of social and cultural expressions. Due to this, the older adults accumulate experiences with which they acquire wisdom and we should learn of this wisdom instead of isolating her.

There arise two dimensions that contrast the oldness: the positive vision and the negative vision. Sarabia-cobo ${ }^{24}$ says that, from the positive vision the oldness is synonymous of wise and experienced, and important persons for the society. However, our older adults do not possess the positive vision but the negative vision about them. From the negative vision, the elder is deficit, because it has generated irreparable and significant losses and because it doesn't have social, physical and familiar independence.

This category demonstrates that; the older adult has a negative thought about himself. The older adult thinks that it doesn't have anything to offer to the society because he feels dependent economic and socially. For this reason, the older adult feels fewer possibilities of going out and to develop as a useful person for the society.

Accordingly, it is necessary to plan strategies that the older adult would demonstrate his real value in the society.

\section{Conclusion}

i. The older adults confront transformations in his life, tied to the social, economic and personal aspects. These transformations it has an impact in his religious beliefs because there is carried out an adaptation process and conscience on the new context of life.

ii. Despite the older adults have problems of health they have the motivation to work because they still want to have economic independence.

iii. The reception centers that take care and protect the older adults, must propose activities to strengthen his quality of life, from other spheres that have an educational and productive conception.

\section{Acknowledgements}

Thanks to our students collaborators Alberto Andrés Alarcón and Juan Carlos Buriticá, the older adults who with his chats and experiences, guided us in this process providing us with wisdom for the life.

\section{Conflict of interest}

The authors demonstrate not to have conflict of interests.

\section{References}

1. Santos E, Silvério I, Tayse A, et al. La percepción del envejecimeinto en una población de ancianos. Cuad los Cuid. 2017;XXI(47):149-158.

2. World Health Organisation, National Institute of Aging (US). Global Health and Ageing; World Health Organisation. Geneva, Switzerland; 2011.

3. Chalapud NLM, Escobar AA. Actividad física para mejorar fuerza y equilibrio en el adulto mayor. Rev Univ y Salud. 2017;19(1):94-101.
4. Orozco R, Molina R. Actividad física, recreación y salud en el adulto mayor. Inter Sedes. 2002;3(4):63-71.

5. Rubio ODY, Rivera ML, Borges OC, et al. Calidad de vida en el adulto mayor. Varona, Rev Científico-Metodológica. 2015;61:1-7.

6. Barbosa MD. Caiu, tchau e bença: os sentimentos , comportamentos e soluções de idosos após a queda em residências unipessoais. Reciis Rev Eletron Comun Inf Inov Saúde. 2017;11(3):1-16.

7. Schaab BL, Duarte MQ, Abs CDV. Estudos para construção e propriedades psicométricas da escala contextual de depressão em idosos. Mudanças -Psicol da Saúde. 2017;25(1):37-47.

8. Rosales RRC, García DRLC, Quiñones ME. Estilo de vida y autopercepción sobre salud mental en el adulto mayor. Medisan. 2014;18(1):61-7.

9. Pinto JM, Neri AL. Trajetórias da participação social na velhice: uma revisão sistemática da literatura. Rev Bras Geriatr e Gerontol. 2017;20(2):260-73.

10. López PB, Fernández PI, Márquez GM. Educación emocional en adultos y personas mayores. Rev Electrónica Investig Psicoeduc. 2008;6(2):50122.

11. Rizo GM. Cuerpo, subjetividad y comunicación en la propuesta filosófica de Maurice-Ponty. Rev Iberiamericana Comun. 2015;28:73-89.

12. Vargas MLM. Sobre el concepto de Percepción. Alteridades. 1994;4(8):47-53.

13. Trujillo GS, Arregocés TM, Milena MS. ¡Que Dios le pague... porque yo no tengo con qué! Reflexión en torno a la inclusión excluyente de personas mayores. Tesis Psicológica. 2016;11(1):272-89.

14. Rivera LA, Montero LLM. Ajuste psicológico y vida religiosa en adultos mayores. Univ Psychol. 2014;13(3):895-906.

15. Rivera LA, Montero LM. Medidas de afrontamiento religioso y espiritualidad en adultos mayores mexicanos. Salud Ment. 2007;30(1):3947.

16. Hernández SR, Fernández CC, Baptista LMP. Metodología de la Investigación. 2014. 634. p.

17. Declaración H. Declaracion de Helsinki. Principios éticos para las investigaciones médicas en seres humanos. Tokio-Japón. Asociación Medica Mundial; 1975. p. 5.

18. Ministerio de Salud y Protección Social. Resolución 8430. 1993. p. 1-12.

19. Rubio M. El silencio de Dios ante el mal. A propósito del film Silencio, de Martin Scorsese. Moralia. 2017;40:191-228.

20. Merino JA. Dios Como Atracción Y Rechazo. 2017;117:552-68.

21. Parra RMA. Diferencias de género en la percepción de salud en personas mayores de 60 años físicamente activas Gender differences in the perception of health in physically active people over 60 years of age. Rev Española Comun en Salud. 2017;8(2):219.

22. Ferrante C. Cuerpo, deporte y discapacidad motriz en la Ciudad de Buenos Aires. Tensiones entre la reproducción y el cuestionamiento a la dominación. Rev Española Discapac. 2013;1(1):159-78.

23. Berumen PR, Gonz CV. Una mirada semiótica y comunicativa a la cultura: del cuerpo y el adorno a la construcción social de sentido. Estud sobre las Cult Contemp. 2013;XIX:67-98.

24. Sarabia CCM, Castanedo PC. Changing negative stereotypes regarding aging in undergraduate nursing students. Nurse Educ Today. 2015;35(9):e60-4. 